\title{
EVALUASI PROGRAM PEMBINAAN DAN PENGEMBANGAN INDUSTRI KECIL DAN MENENGAH DI KABUPATEN PONOROGO
}

\author{
Dina Trisiana Iskandar \\ Fakultas Ilmu Administrasi Universitas Brawijaya,d_trisiana03@yahoo.com
}

Sumartono dan Tjahjanulin Domai

Fakultas Ilmu Administrasi Universitas Brawijaya

\begin{abstract}
Abstrak
Penelitian ini bertujuan untuk mengevaluasi pelaksanaan program pembinaan dan pengembangan IKM di Kabupaten Ponorogo dengan model evaluasi CIPP. Metode penelitian yang digunakan adalah evaluasi deskriptif dengan pendekatan kualitatif. Evaluasi Konteks menunjukkan bahwa program ini sejalan dengan tujuan Dinas Indakop dan UKM dalam menumbuhkan jumlah wirausaha baru dan meningkatkan keterampilan SDM. Evaluasi Masukan, meliputi: perencanaan program, anggaran, SDM aparatur, kondisi peserta dan sarana prasarana. Evaluasi Proses menunjukkan pelatihan teknis lebih banyak diberikan dibanding non-teknis. Dalam pelaksanaannya, masih minimnya evaluasi pelatihan. Evaluasi hasil menunjukkan bahwa tujuan program berupa peningkatan keterampilan belum sepenuhnya optimal, sedangkan pada tujuan penumbuhan wirausaha baru belum dapat terukur.
\end{abstract}

Kata Kunci: pengembangan IKM, evaluasi program, CIPP

\begin{abstract}
The purpose of this research is to evaluate implementation of SME development program using CIPP model. This evaluation used qualitative approach method. The context evaluation revealed that the task of Department of Industry, Trade, Cooperative and SMEs Ponorogo Regency. The input evaluation includes: development program, budgets, manpower, conditions of participants and facilities. In the process evaluation, showed that technical training is given more than non-technical. The product evaluation, the objectives program to increase the skills have not been fully optimized, while the growth of new entrepreneur objectives cannot be measured due to lack of training evaluation.
\end{abstract}

Keywords: SME development, evaluation program, CIPP

\section{PENDAHULUAN}

Perencanaan pembangunan daerah dalam konteks pembangunan nasional memiliki peran dan fungsi yang sangat penting bagi pencapaian tujuan-tujuan pembangunan nasional. Dengan diberlakukannya otonomi daerah yang lebih luas, nyata dan bertanggung jawab, setiap daerah dituntut untuk mampu mengelola daerahnya secara mandiri. Indonesia sebagai negara Dunia Ketiga, memiliki kekayaan alam tidak lantas terbebas dari masalah pembiayaan karena keterbatasan dalam menggali kekayaan alam dan mentransformasikannya dari potensi menjadi kekuatan nyata untuk penyelenggaraan pembangunan nasional (Siagian, 1988:55). Sehingga untuk mengejar ketertinggalan, maka pembangunan nasional difokuskan terhadap pembangunan di bidang ekonomi.

Mengacu pada fokus prioritas pembangunan industri, salah satu langkah dalam mencapai pembangunan ekonomi lokal adalah keterlibatan masyarakat dalam memanfaatkan sumberdaya lokal melalui pemberdayaan IKM. Hal ini tertuang dalam
Undang Undang Nomor 3 Tahun 2014 tentang Perindustrian, yang mengamanatkan pembangunan industri melalui penguatan struktur industri yang mandiri, sehat dan berdaya saing dan maju untuk kemakmuran dan kesejahteraan masyarakat. Selain berkontribusi terhadap perekonomian, IKM juga memiliki keunggulan resisten terhadap terpaan krisis global, mudah ditumbuhkembangkan di suatu daerah, dimana dapat menimbulkan dampak untuk meningkatkan pendapatan daerah secara cepat yang melibatkan partisipasi masyarakat secara luas, sehingga sebagai penggerak ekonomi di daerah (Pusdiklat Industri, 2012).

Kabupaten Ponorogo memiliki nilai komparatif berupa ketersediaan lahan pertanian yang subur sehingga merupakan daerah berbasis sektor primer, dengan kontibusi sektor pertanian, kehutanan dan perikanan terhadap Pendapatan Regional Domestik Bruto (PDRB) Kabupaten Ponorogo pada tahun 2014 mencapai 31,80\% dengan nilai Rp.4.274.965,4 juta. Sedangkan kontribusi PDRB dari sektor industri pengolahan hanya sebesar 6,75\% dengan nilai Rp.906.868,86 juta (BPS Kabupaten Ponorogo, 2015). 
Berdasarkan data tersebut, apabila mengandalkan kekuatan sektor primer saja belum cukup signifikan dalam meng-entaskan kemiskinan. Tercatat jumlah penduduk misikin Ponorogo tahun 2013 sebanyak $11,92 \%$ atau 103.000 jiwa dengan garis kemiskinan Rp.239.963 per kapita/bulan, dimana nilai tersebut di bawah garis kemiskinan di Jawa Timur sebesar Rp.273.758 per kapita/bulan (BPS Jawa Timur, 2015).

Sehingga, tidak cukup hanya mengandalkan nilai tawar komparatif, perlu adanya nilai tawar kompetitif salah satunya melalui pemberdayaan sektor IKM. Sama halnya daerah lain, corak struktur industri di Kabupaten Ponorogo sebagian besar merupakan IKM, dengan jumlah industri pada tahun 2014 sebanyak 3 industri besar, 22 industri sedang dan IKM sebanyak 19.706 unit. Akan tetapi sektor IKM belum mampu menyerap lapangan pekerjaan secara optimal. Hal ini terlihat masih tingginya minat penduduk Ponorogo untuk mendaftarkan diri sebagai Tenaga Kerja Indonesia (TKI). Menurut data Dinas Sosial, Tenaga Kerja dan Transmigrasi banyaknya TKI/TKW yang berangkat ke Luar Negeri pada tahun 2014 sebanyak 4.039 orang, Menurut Spicer dalam Rakicevic (2015:31) pentingnya keberadaan IKM dikenal sebagai motor penggerak pertumbuhan ekonomi nasional, regional dan pengembangan sumberdaya lokal, serta sebagai alat untuk mencegah perpindahan penduduk dari area geografi-ekonomi yang pasif.

Pemerintah Kabupaten Ponorogo melalui Dinas Indakop dan UKM turut serta dala upaya pembangunan ekonomi dari sektor industri melalui program pembinaan dan pengembangan IKM. Adapun sasaran program ini berupa meningkatnya kualitas dan kuantitas hasil industri unggulan daerah dengan indikator, yaitu: (1) kontribusi sektor industri terhadap PDRB; dan (2) penumbuhan industri baru. Berdasarkan data LAKIP Dinas Indakop dan UKM Tahun 2015, tercatat kontribusi sektor industri terhadap PDRB memiliki target pada akhir tahun Renstra sebesar 9,51\% dengan realisasi $6,75 \%$. Sedangkan pada indikator kedua, memiliki target akhir penumbuhan industri baru sebesar $0,60 \%$ dengan realiasasi hanya $0,20 \%$.

Berdasarkan permasalahan tersebut dimana hingga akhir tahun perencanaan belum mampu mencapai target yang diharapkan, maka penulis tertarik untuk menganalisis dan mengevaluasi pelaksanaan program pembinaan dan pengembangan IKM di Kabupaten Ponorogo melalui model evaluasi CIPP (Context-InputProcess-Product).

Pemilihan evaluasi pada periode lalu 2010-2015, dikarenakan adanya pergantian Kepala Daerah yang baru (bukan petahana), sehingga hasil evaluasi ini diharapkan dapat memberikan masukan kepada Bupati terpilih mengenai permasalahan pelaksanaan program pembinaan dan pengembangan IKM di Kabupaten Ponorogo.

\section{METODE}

Penelitian evaluasi ini menggunakan pendekatan kualitatif deskriptif dengan fokus penelitian, yaitu mengevaluasi pelaksanaan program pembinaan dan pengembangan IKM di Kabupaten Ponorogo, meliputi: (1) evaluasi konteks (context); (2) evaluasi masukan (input); (3) evaluasi proses (process); dan (4) evaluasi hasil (product).

Sumber data yang digunakan dalam penelitian ini berupa:

a. Informan, yang dipilih secara purposif (purposive sampling), yakni sebanyak 7 (tujuh) orang pejabat dan staf di Dinas Indakop dan UKM dan 1 (satu) orang pejabat Bappeda, serta 12 (dua belas) orang pengrajin IKM sebagai sasaran penerima program, yang terbagi 6 (enam) pengrajin IKM yang telah dan 6 (enam) pengrajin IKM belum mendapatkan pembinaan.

b. Tempat dan Peristiwa, penelitian ini bertempat di Dinas Indakop dan UKM dan Bappeda Kabupaten Ponorogo serta lokasi produksi pengrajin IKM.

c. Dokumen, meliputi: Renstra, Renja dan Lakip Dinas Indakop dan UKM, RPJM Kabupaten Ponorogo serta dokumen lain yang terkait pelaksanaan Program pembinaan dan pengembangan IKM

Adapun teknik pengumpulan data dilakukan dengan cara observasi, wawancara dan dokumentasi. Analisis data yang digunakan, yaitu:

1. Model analisis evaluasi kualitatif seperti yang dikembangkan oleh Quinn Patton (2006:252-255) yang terdiri dari 3 (tiga) komponen, yakni: (1) memfokuskan analisis; (2) mengorganisasikan data kualitatif untuk analisis; dan (3) deskripsi kualitatif yang mencakup deskripsi murni tentang program dan pengalaman orang dalam program.

2. Model evaluasi CIPP (Context, Input, Process, Product) yang dikembangkan oleh Stufflebeam. Keunggulan model CIPP memberikan suatu format evaluasi yang komprehensif pada setiap tahapan evaluasi yaitu tahap konteks, masukan, proses, dan produk (Arikunto, 2009)

\section{HASIL DAN PEMBAHASAN}

\section{Evaluasi Konteks (Context)}

Menurut Stufflebeam dalam Sukardi (2008) bahwa evaluasi konteks, menghasilkan informasi tentang macam-macam kebutuhan yang telah diatur prioritasnya, agar tujuan dapat diformulasikan. Berdasarkan informasi 
yang diperoleh bahwa tujuan diadakannya program pembinaan dan pengembangan IKM di Kabupaten Ponorogo sudah sejalan dengan tujuan dari Dinas Indakop dan UKM Kabupaten Ponorogo, dimana salah satunya bertujuan untuk menumbuhkan dan mengembangkan IKM di Kabupaten Ponorogo yang tangguh, professional dan berdaya saing. Hal tersebut mengacu kepada skenario pembangunan ekonomi Kabupaten Ponorogo, sebagaimana termuat dalam RPJMD Kabupaten Ponorogo, yaitu Pembangunan Ekonomi yang Inklusif dan Berkeadilan, dengan strategi pembangunan pro-growth, pro-job, pro-poor, pro-gender dan pro enviroment, untuk memberikan arah pembangunan yang benar, menyeluruh, berkeadilan dan berkelanjutan.

\section{Evaluasi Masukan (Input)}

Dalam program pembinaan dan pengembangan IKM terdapat sumber-sumber masukan, antara lain:

\section{Perencanaan Program}

Perencanaan program ini berdasarkan Renstra Dinas Indakop dan UKM Kabupaten Ponorogo tahun 2010-2015 dimaksudkan untuk memberikan arah (road map) untuk mencapai visi dan misi Dinas Indakop dan UKM dalam upaya pencapaian misi kedua dari perencanaan pembangunan daerah sesuai dengan RPJMD. Kemudian, perencanaan dalam Renstra tersebut dijabarkan dalam Rencana Kerja (Renja) setiap tahunnya.

Menurut Tjiptoherijanto (2010:120) bahwa perencanaan adalah langkah awal yang sangat penting dan strategis, dimana mencakup beberapa aspek penting, yaitu: (1) definisi yang jelas tentang apa yang akan dicapai pada waktu yang akan datang; (2) definisi yang jelas tentang apa yang dihadapi saat ini; dan (3) kemampuan menyusun alternatif-alternatif pengambilan keputusan yang konsisten namun fleksibel

Tabel 1. Perkembangan Jumlah Industri di Kabupaten

Ponorogo

\begin{tabular}{cccccr}
\hline Jenis & \multicolumn{5}{c}{ Jumlah (unit) } \\
\cline { 2 - 6 } Industri & $\mathbf{2 0 1 0}$ & $\mathbf{2 0 1 1}$ & $\mathbf{2 0 1 2}$ & $\mathbf{2 0 1 3}$ & $\mathbf{2 0 1 4}$ \\
\hline Besar & 7 & 5 & 4 & 6 & 3 \\
Sedang & 38 & 37 & 43 & 18 & 22 \\
Kecil & 21.789 & 21.857 & 21.872 & 19.685 & 19.706 \\
\hline Jumlah & 21.834 & 21.899 & 21.919 & 19.709 & 19.731 \\
\hline Sumber: Ponorogo Dalam Angka (2015:218)
\end{tabular}

Tabel 2. Profil IKM Ponorogo Tahun 2014

\begin{tabular}{cccc}
\hline $\begin{array}{c}\text { Jenis } \\
\text { IKM }\end{array}$ & $\begin{array}{c}\text { Jumlah } \\
\text { (Unit) }\end{array}$ & $\begin{array}{c}\text { Tenaga Kerja } \\
\text { (Jiwa) }\end{array}$ & $\begin{array}{c}\text { Nilai Produksi } \\
\text { (Rp. - -000) }\end{array}$ \\
\hline Formal & 617 & 6.452 & 734.381 .207 \\
$\begin{array}{c}\text { Non } \\
\text { Formal }\end{array}$ & 19.089 & 39.432 & 177.503 .061 \\
\hline Jumlah & 19.706 & 45.884 & 911.333 .923 \\
\hline
\end{tabular}

Sumber: Ponorogo Dalam Angka (2015:220)
Secara umum, proses penyusunan perencanaan program pembinaan dan pengembangan IKM di Kabupaten Ponorogo telah menggunakan kolaborasi topdown dan bottom-up, akan tetapi dengan porsi perencanaan top-down lebih besar dibandingkan dengan bottom-up. Perencanaan Top-down ini terlihat pada saat penentuan dasar prioritas dan kerangka pembangunan serta menjembatani rencana dari institusi yang lebih tinggi dalam hal ini, yaitu Kementerian Perindustrian sebagai perencana dalam pembangunan IKM skala nasional. Sedangkan perencanaan bottom-up dilakukan Dinas Indakop dan UKM dengan menampung kebutuhan masyarakat dalam meningkatkan usaha IKM melalui usulan yang disampaikan dalam Musrenbang maupun secara langsung. Seperti yang disampaikan oleh Kuncoro (2004:58) bahwa sistem perencanaan pembangunan dengan mengunakan top-down dan bottom-up akan menjamin adanya keseimbangan antara prioritas nasional dengan aspirasi lokal dalam perencanaan pembangunan daerah.

Berdasarkan hasil evaluasi dokumen Renstra dan Renja masih terdapat ketidaksesuaian terhadap Permendagri Nomor 54 tahun 2010 Tetang Pelaksanaan Peraturan Pemerintah Nomor 8 Tahun 2008 Tentang Tahapan, Tatacara Penyusunan, Pengendalian dan Evaluasi Pelaksnaan Rencana Pembangunan Daerah, diantaranya belum mencantumkan peraturan tersebut sebagai landasan hukum, sehingga terdapat ketidaksesuaian sistematika penulisan serta pengesahan Renstra yang seharusnya oleh Bupati, namun hanya disahkan oleh Kepala Dinas, sehingga menjadi lemahnya legalitas dokumen perencanaan.

Demikian evaluasi terhadap dokumen Renja, hanya dilakukan terhadap telah/belum terlaksananya kegiatan, tetapi belum dapat diketahui bagaimana konsistensinya terhadap pencapaian target telah direncanakan berdasarkan dalam Renstra. Selain itu belum adanya telaah terhadap Kebijakan Nasional, Penelaahan usulan masyarakat; dan Perumusan kegiatan prioritas. Kelemahan aspek dalam perencanaan ini berakibat dalam proses implementasinya.

\section{Sumberdaya manusia (SDM) aparatur bidang Industri}

Dalam menjalankan tugasnya, bidang Industri hanya memiliki SDM sebanyak 13 (tiga belas) orang, yang terdiri 1 (satu) orang kepala Bidang, 3 (tiga) orang Kepala Seksi (IKBB, IHPK dan ILMEA), 6 (enam) orang staf dan 3 (tiga) orang fungsional penyuluh perindustrian. Menurut informan bahwa keterbatasan jumlah aparat masih merupakan hambatan dalam pelaksanaan program, sehingga belum mampu menjangkau ke keseluruhan wilayah Kabupaten Ponorogo. Hal serupa juga 
disampaikan Ridwan (2014:1352) bahwa keterbatasan jumlah aparat merupakan salah satu faktor penghambat pelaksanaan upaya pembinaan IKM pada Dinas Perindagkop dan UMKM Kota Bontang.

Sementara itu, secara kualitas SDM aparatur Bidang Industri telah memenuhi persyaratan kompetensi, dimana berlatar belakang pendidikan formal yang mayoritas Sarjana Teknik. Selain itu keikut sertaan dalam pendidikan non formal berupa diklat-diklat industri yang sangat mendukung pekerjaan.

Sebagaimana disampaikan oleh Tjiptoherijanto (2010:123) kegagalan dalam pelaksanaan kebijakan publik lebih sering disebabkan oleh faktor-faktor internal, yaitu lemahnya daya dukung administrasi terhadap pelaksanaan kebijakan public, yang mencakup struktur organisasi, kemampuan manajerial, kemampuan keuangan serta jumlah dan kualitas SDM yang tersedia.

\section{Sumberdaya Anggaran}

Sumberdaya anggaran dalam pelaksanaan program ini berasal dari APBD Kabupaten Ponorogo, dimana pada tahun 2011 berasal dari Dana Bagi Hasil Cukai Tembakau (DBHCT) dan pada tahun 2012 hingga 2015 berasal dari Dana Alokasi Umum (DAU). Adapun jumlah anggaran program ini pada tahun 2011-2015 berturut-turut, yaitu: Rp.430.400.000; Rp. 808.503.000; Rp.695.000.000; Rp. 1.200 .000 .000 dan Rp. 1.068.426.000.

Jumlah anggaran yang berfluktuatif, dipengaruhi oleh tingkat APBD dan prioritas peruntukkannya. Serta melihat tingkat kepentingan program pembinaan dan pengembangan IKM yang merupakan bagian dari perindustrian, dimana berdasarkan Undang Undang Nomor 23 Tahun 2014 tentang Pemerintahan Daerah merupakan salah satu Urusan Pemerintahan Pilihan, sehingga tidak dapat dipastikan pagu anggaran untuk melaksanakan program ini setiap tahunnya.

Berdasarkan hasil wawancara kepada informan bahwa anggaran merupakan permasalahan yang krusial, sehingga apabila minimnya anggaran yang diterima berakibat pada jumlah dan durasi penyelenggaran kegiatan. Diperlukannya suatu perencanaan yang efektif dan efisien dalam mengalokasikan sumber daya anggaran yang terbatas dalam merumuskan jenis pelatihan yang dibutuhkan oleh pengrajin IKM pada tahun berikutnya agar mampu mengakomodir kebutuhan IKM dengan skala prioritas.

\section{Kondisi Peserta Program.}

Meninjau kembali pada tujuan program ini, yakni:

(1) meningkatkan keterampilan SDM pengrajin IKM; dan

(2) menumbuhkan calon wirausaha baru, sehingga calon peserta program terbagi menjadi 2 (dua) jenis, yaitu: (1) pengrajin IKM yang telah memiliki usaha; dan (2) calon wirausaha baru.

Berdasarkan hasil wawancara mendalam terhadap salah satu pengrajin IKM yang menjadi wirausaha baru bermula dari keikutsertaan pelatihan keterampilan pembuatan kue dalam pelatihan Pembinaan Industri di Lokasi P2WKSS yang merupakan kerjasama dengan Kantor P3A dalam upaya memberdayakan kaum perempuan yang tidak bekerja, menjadi produktif dengan membuka usaha sehingga dapat membantu perekonomian keluarga.

\section{Sarana dan Prasarana}

Dalam menyelenggarakan pelatihan, Bidang Industri Dinas Indakop dan UKM telah memberikan sarana dan prasarana yang cukup memadai diantaranya: (a) gedung pelatihan, dilengkapi sarana penunjang seperti: meja dan kursi peserta, proyektor, laptop. (b) narasumber / pelatih yang berkompeten sesuai dengan bidang usahanya; (c) metode pembelajaran yang dikombinasikan metode ceramah dan interaktif; dan (d) waktu pelatihan yang cukup antara teori dan praktek.

\section{Evaluasi Prosess (Process)}

Proses pelaksanaan program pembinaan dan pengembangan IKM berdasarkan Dokumen Pelaksanaan Anggran (DPA) Dinas Indakop dan UKM. Akan tetapi dari sisi administratif, pelaksanaan program ini belum mengacu kepada dokumen perencanaan diatasnya, yakni Renja, Renstra dan RPJMD.

Secara umum, program ini dilaksanakan dalam jenis pelatihan teknis dan pelatihan non-teknis (manajerial), dimana jumlah pelatihan teknis yang diberikan lebih banyak, hal ini sudah tepat untuk mencapai tujuan program dalam meningkatan keterampilan SDM pengrajin serta berupaya meningkatkan pertumbuhan wirausaha baru. Sedangkan pelatihan non-teknis bersifat manajerial diperuntukkan bagi pengrajin IKM yang telah memiliki usaha

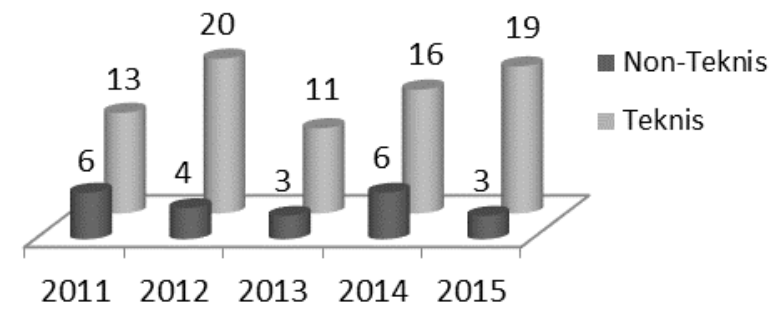

Gambar 1. Grafik Jumlah dan Jenis Pelatihan Tahun 2011-2015

Sumber: Dokumen Pelaksanaan Kegiatan Bidang Industri (diolah) 
Menurut Wahjono (2015:76) menjelaskan langkah-langkah umum dalam proses pelatihan dan pengembangan, yaitu: (1) penilaian dan analisis kebutuhan, (2) desain program pelatihan, (3) pengembangan program pelatihan; (4) pelaksanaan dan penyampaian pelatihan; dan (5) evaluasi pelatihan.

Berdasarkan teori tersebut, Bidang Industri telah menerapkan beberapa diantaranya, namun belum keseluruhan diterapkan, khususnya dalam tahap evaluasi pelatihan, baru hanya pada saat pelatihan Fasilitasi Sertifikasi Produk Industri Makanan Minuman, dimana terdapat evaluasi berupa peningkatan pengetahuan sebelum dan sesudah pelatihan berupa pre-test dan posttest.

Seharusnya penerapan evaluasi ini dilakukan pada seluruh pelatihan yang diselenggarakan agar dapat terukur berapa besar penyerapan materi oleh peserta, serta bagaimana pencapaian target output pelatihan terhadap indikator kinerja.

\section{Evaluasi Hasil (Product)}

Wujud hasil dari program ini adalah penyelenggaraan kegiatan yang memfasilitasi kebutuhan pengrajin IKM yang bertujuan: (1) meningkatkan keterampilan SDM pengrajin IKM; dan (2) menumbuhkan calon wirausaha baru. Akan tetapi tujuan program tersebut belum dapat terukur, hal ini disebabkan indikator keluaran (output) yang tercantum dalam Dokumen Pelaksanaan Anggaran (DPA) berupa: meningkatnya kualitas kualitas SDM, mutu produk, desain manajemen, masih belum memenuhi kriteria yang tercantum dalam Peraturan Presiden RI Nomor 29 Tahun 2014 tentang Sistem Akuntabilitas Kinerja Instansi Pemerintah, yakni SMART (Specific, Measurable, Attainable, Time bound dan Trackable). Indikator output dari setiap pelaksanaan kegiatan yang tidak spesifik, menyebabkan kesulitan dalam mengkur bagaimana capaiannya. Selanjutnya output dari pelaksanaan kegiatan tidak dapat diketahui bagaimana perannya dalam mendukung terhadap pencapaian indikator kinerja yang telah tertulis pada Renstra, yaitu: (1) kontribusi sektor industri terhadap PDRB; dan (2) penumbuhan industri baru.

Berdasarkan hasil wawancara diketahui bahwa responden dari kelompok IHPK (industri kimia pertanian dan kehutanan) mengalami peningkatan dalam keterampilan pengolahan produk olahan pangan dan peningkatan dalam desain kemasan. Pada kelompok IKBB (industri kimia dan bahan bangunan) sebagian belum memberikan peningkatan keterampilan dalam produksi karena jenis pelatihannya berupa motivasi, sedangkan pada kelompok ILMEA (industri logam mesin dan aneka) terdapat IKM yang telah mengikuti program pelatihan tidak sesuai dengan latar belakang usahanya, sehingga dapat disimpulkan pelaksanaan program belum optimal. Sedangkan pada tujuan kedua dalam program, yaitu penumbuhan wirausaha baru belum dapat terukur karena minimnya evaluasi pasca pelatihan seperti yang telah dijelaskan sebelumnya.

Menurut data Laporan Akuntabilitas Kinerja Instansi Pemerintah (LAKIP) Dinas Indakop dan UKM terlihat adanya ketimpangan capaian realisasi terhadap target. Hal tersebut diungkapkan oleh salah seorang informan yang menyatakan belum dilakukannya peninjauan kembali (review) terhadap target pada tahun berjalan yang disesuaikan dengan kemampuan capaian karena serta kondisi ketidakstabilan ekonomi daerah yang menyebabkan penurunan jumlah industri pada tahun 2013.

Perencana program seharusnya lebih spesifik dalam merumuskan indikator kinerja, dimana bukan berupa kontribusi PDRB dari sektor industri pengolahan melainkan hanya melalui sektor industri kecil saja. Hal ini dimungkinkan terdapat kontribusi yang lebih besar yang diperoleh dari sektor industri besar dan menengah, walaupun dengan jumlah yang sedikit. Selain itu, indikator pertumbuhan industri juga harus di spesifikan menjadi pertumbuhan IKM saja yang disesuaikan dengan tugas pokok dan fungsi dari Dinas Indakop dan UKM adalah membina IKM.

Tabel 3. Perbandingan Target Dan Realisasi Kinerja Dinas Indakop dan UKM

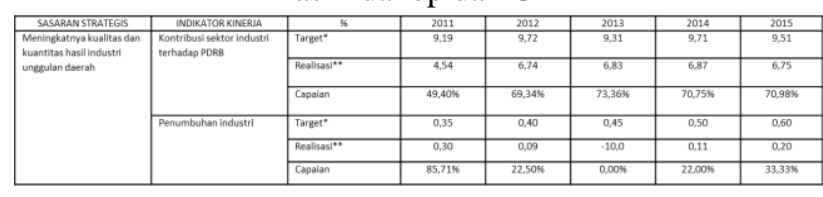

Sumber:

*) RPJMD Kabupaten Ponorogo

**) LAKIP Dinas Indakop dan UKM (diolah)

\section{PENUTUP}

\section{Simpulan}

Beberapa kesimpulan dari penelitian ini dirumuskan sebagai berikut :

1. Evaluasi konteks menunjukkan bahwa tujuan program pembinaan dan pengembangan IKM telah sejalan dengan tujuan dari Dinas Indakop dan UKM Kabupaten Ponorogo.

2. Evaluasi masukan, meliputi:

a. Perencanaan Program yang telah menggunakan kolaborasi top-down dan bottom-up, dengan porsi top-down yang lebih besar

b. Keterbatasan sumber daya anggaran, yang dipengaruhi oleh tingkat APBD dan prioritas peruntukkannya; 
c. Keterbatasan sumberdaya manusia (SDM) aparatur hanya 13 orang;

d. Kondisi peserta program, yakni pengrajin IKM yang telah memiliki usaha dan calon wirausaha baru;

e. Sarana dan prasarana yang cukup memadai.

3. Evaluasi proses menunjukkan pelatihan teknis lebih banyak diselenggarakan. Masih rendahnya evaluasi yang dilakukan terhadap setiap pelatihan yang diselenggarakan, agar dapat terukur berapa persen penyampaian materi oleh peserta, serta bagaimana pencapaian target output pelatihan terhadap indikator kinerja.

4. Evaluasi hasil menunjukkan bahwa tujuan program berupa peningkatan keterampilan belum sepenuhnya optimal, sedangkan pada tujuan penumbuhan wirausaha baru belum dapat terukur karena minimnya evaluasi pasca pelatihan..

\section{DAFTAR PUSTAKA}

Arikunto, Suharsimi dan Cepi Safrudin. (2009). Evaluasi Program Pendidikan: Pedoman Teoritis Praktis Bagi Mahasiswa dan Praktisi Pendidikan. Jakarta: Bumi Aksara.

Badan Pusat Statistik. (2015). Ponorogo Dalam Angka 2015. Ponorogo: BPS Kabupaten Ponorogo.

Badan Pusat Statistik. (2015). Jawa Timur Dalam Angka 2015. Surabaya: BPS Provinsi Jawa Timur.

Dunn, William N. (2003). Analisis Kebijakan Publik. Yogyakarta: Gajah Mada University Press.
Kuncoro, Mudrajad. (2004). Otonomi dan Pembangunan Daerah: reformasi, Perencanaan, Strategi, dan Peluang. Jakarta: Erlangga.

Kuncoro (2007). Ekonomika Industri Indonesia: Menuju Negara Industri Baru 2030? Yogyakarta: Penerbit Erlangga.

Patton, Michael Quinn. (2006). Metode Evaluasi Kualitatif. Diterjemahkan oleh Budi Puspo Priyadi. Yogyakarta: Pustaka Pelajar.

Pusdiklat Industri. (2012). Modul Diklat SIstem Industri I: Manajemen IKM. Jakarta: Kementerian Perindustrian.

Rakicevic, Z., Jasmina O.B. and Danice L.C. (2016). ”A Model for Effective Planning of SME Support Services". Elsevier Evaluation and Program Planning Journal,54,30-40.

Ridwan, M. (2014). Pembinaan Industri Kecil dan Menengah Pada Dinas Perindustrian , Perdagangan, Koperasi dan UMKM Kota Bontang. Dalam eJurnal Administrative Reform, 2, (3): 1341-1354.

Riyadi dan Bratakusumah, Deddy Supriady. (2004). Perencanaan Pembangunan Daerah: Strategi Menggali Potensi Dalam Mewujudkan Otonomi Daerah. Jakarta: PT Gramedia Pustaka Utama.

Tjiptoherijanto, Prijono dan Mandala Manurung. (2010). Paradigma Administrasi Publik Dan Perkembangannya. Jakarta: Penerbit Universitas Indonesia (UI Press).

Wahjono, Sentot Imam (2015). Manajemen Sumber Daya Manusia. Jakarta: Penerbit: Salemba Empat.

Widodo, Joko (2013). Analisis Kebijakan Publik: Konsep dan Aplikasi Analisis Proses Kebijakan Publik. Malang: Bayumedia Publishing. 